\title{
Effect of Planting Density on Growth and Productivity of Pomegranate Trees
}

\author{
A. S. El- Khawaga ${ }^{*}$, M. Abo El-Wafa* ${ }^{*}$ and A.S. Mofeed \\ *Department of Horticlture, Faculty of Agriculture, South \\ Valley University, Qena and ${ }^{* *}$ Olive \& Semi-arid Zone Fruits \\ Research Department, Horticulture Research Institute, \\ Agricultural Research Centre, Cairo, Egypt.
}

\begin{abstract}
A FIELD study was conducted during two successive seasons of 2010 and 2011 in a private orchard at Sohag Governorate, Egypt. The performance of two pomegranate cultivars (Manfalouty and Nab El-Gamal) under two levels of plant spacing $(2.5 \times 2.5 \mathrm{~m})$ and $(4 \times 4 \mathrm{~m})$ at the newly reclaimed sandy soil was studied. Results revealed that, $(2.5 \times 2.5 \mathrm{~m})$ plant spacing recorded the highest significant values of tree height, yield/feedan, peel thickness and percentage of marketable fruits. In addition, it reduced percentage of disordered fruits (sun burned and cracked), while it affected negatively on (trunk girth, canopy volume, perfect flowers/tree, initial fruit set/tree, number of fruits/tree, yield/tree, fruit weight, total sugars and total soluble solids) which gave the highest values with $(4 \times 4 \mathrm{~m})$ treatment. Moreover, Manfalouty cultivar recorded the highest significant values in most characteristics compared to Nab El-Gamal.

It could be recommended that, under the same conditions of the present study, Manfalouty cultivar trees could be planted under the level of plant spacing $(2.5 \times 2.5 \mathrm{~m})$.
\end{abstract}

Keywords: Pomegranate, Planting density, Plant spacing, Productivity, Fruit disorders, Manfalouty, Nab El-Gamal.

Pomegranate (Punica granatum) is a naturally dense, deciduous, bushy, multistemmed shrub or small tree. It belongs to punicace family and is one of the oldest known edible fruits. Recent consumption of pomegranates has rapidly increased attributable in part to its reported health benefits that include efficacy against a wide range of diseases, including coronary heart disease, atherosclerosis, prostate cancer, hypertension, and infectious diseases (Seeram et al., 2006, Lansky \& Newman, 2007, Basu \& Penugonda, 2008 and Holland et al., 2009). It is well known that pomegranate grows in semi-arid climate, and is extremely drought tolerant (Soliman, 1992, Abo-Taleb et al.,1998 and Abouelwafa, 2006). Pomegranate is a high value crop and its entire tree is of great economic importance. Apart from its demand for fresh fruits and juice, the processed products like wine and candy are also gaining importance in the world trade. The pomegranate area of Egypt was estimated to be about 13,000 Fadden (Ministry of Agriculture and Reclaimed Lands Statistics, 2012). This area is mainly concentrated in Upper Egypt governorates (about 66\%) and many farmers relied 
on it for their living as a major source of income. Manfalouty and Nab El-Gamal pomegranate are the most important commercial cultivars grown in Egypt especially in Upper Egypt governorates.

Tree spacing has become an increasingly important consideration in fruit crops orchards management. Generally, closely-planted orchards provide greater and earlier returns but with a demand for precise management if problems are not to be encountered with time, growers want earlier net returns on their investment and expect them to be maximized over the productive life of the grove. Selection of tree spacing and management philosophy to achieve these goals is a complex subject to many considerations, and provides for great debate and challenge. The move toward higher planting densities was partially the result of an intensified constraint on growers of tree crops due to reduced land and water availability, more stringent land use regulations, the desire for earlier economic return on investment and a need for increased management efficiency (Tucker et al., 1994). Planting density has the most influence on the yield. As density increased, yield per tree decreased, but yield/ha increased. The chief advantage of high density was a large increase in early fruit yield per hectare (Hampson et al., 2004). The concept of high density is increasing by gaining acceptance to optimize productivity. Contradictory reports are available in the international literature regarding high density planting on fruit quality of citrus fruits. Chadha (2001) mentioned that, as in the close planting, plants grow tall and are damaged by strong winds and produce low yields, poor fruit size, inferior quality, the trees appear sick and are prone to rapid attack of insects and diseases. Moreover, at high planting density Saxena and Sharma (2004) found reduction in fruit size in Frost Navel Oranges. Donadio et al. (1995) reported poor color development in Pera oranges, though fruit size and quality were not influenced by different planting densities. However, Hunton (1986) found no detrimental effect on fruit size and quality of Valencia late oranges. Goswami et al. (1993) reported excellent color and quality of Kinnow fruit under high planting density.

Consequently, this study was carried out to investigate the effect of planting density on growth and yield as well as fruit physical and chemical characteristics of Manfalouty and Nab El-Gamal pomegranate trees grown in the new reclaimed lands.

\section{Materials and Methods}

The present study was conducted during two successive seasons of 2011 and 2012 on two pomegranate cvs. (Manfalouty and Nab-ELGamal) to determine the effect of tree spacing on vegetative growth, flowering, fruit set and productivity as well as physical and chemical fruit characteristics. Both cultivars were planted at two spacing $(2.5 \times 2.5 \mathrm{~m})$ and $(4 \times 4 \mathrm{~m})$, whereas the $2^{\text {nd }}$ one was applied on most of pomegranate orchards in Egypt, providing tree densities of 672 and 262 trees per feddan, respectively. Trees were about 5 years old grown on a loamy sandy soil (newly reclaimed lands) under drip irrigation system at a private orchard on Tema district, Sohag Governorate, South Egypt. In each season, 60 
pomegranate trees of each investigated cultivar were selected, particularly uniform in growth and healthy. The experiment was set in a randomized complete block design with two treatments; each treatment was represented by three replicates (10 trees/each).

Some physical and chemical analyses of the experiment soil are shown in Tables (A\&B).

TABLE A. Physical characteristics of the soil.

\begin{tabular}{|l|c|c|c|c|c|}
\hline \multirow{3}{*}{ Depth } & \multicolumn{4}{|c|}{ Particle size distribution } & \multirow{2}{*}{ Texture } \\
\cline { 2 - 5 } & $\begin{array}{c}\text { Coarse sand } \\
\mathbf{\%}\end{array}$ & $\begin{array}{c}\text { Fine sand } \\
\mathbf{\%}\end{array}$ & $\begin{array}{c}\text { Silt } \\
\mathbf{\%}\end{array}$ & $\begin{array}{c}\text { Clay } \\
\mathbf{\%}\end{array}$ & \\
\hline $0-30$ & 52.00 & 30.8 & 9.6 & 7.6 & Sandy loam \\
\hline $30-60$ & 51.00 & 29.4 & 10.9 & 8.2 & Sandy loam \\
\hline
\end{tabular}

TABLE B. cont. Chemical characteristics of the soil.

\begin{tabular}{|l|c|c|c|c|c|c|c|c|c|}
\hline \multirow{2}{*}{ Depth } & \multicolumn{4}{|c|}{$\begin{array}{c}\text { Soluble cations } \\
\text { (meq/L) }\end{array}$} & \multirow{2}{*}{ pH } & \multirow{2}{*}{$\begin{array}{c}\text { Ec } \\
\text { dS/m }\end{array}$} & \multicolumn{3}{|c|}{$\begin{array}{c}\text { Soluble anions } \\
\text { (meq//) }\end{array}$} \\
\cline { 2 - 6 } & $\mathrm{Ca}^{++}$ & $\mathrm{Mg}^{++}$ & $\mathrm{Na}^{++}$ & $\mathrm{K}^{++}$ & & & $\mathrm{Cl}^{-}$ & $\mathrm{Hco}_{3}{ }^{-}$ & $\mathrm{So}_{4}^{--}$ \\
\hline $0-30$ & 14.71 & 13.18 & 13.60 & 1.4 & 7.60 & 4.18 & 7.11 & 2.71 & 32.80 \\
\hline $30-60$ & 8.05 & 7.56 & 4.16 & 0.72 & 7.65 & 2.01 & 3.48 & 2.96 & 14.05 \\
\hline
\end{tabular}

Field observations and laboratory measurements were recorded during the two seasons of this research as follows:

Vegetative growth measurements

Tree height $(\mathrm{m})$

Measured on mid - July from the soil surface to the highest point of the tree for each spacing during the two experiment seasons.

Trunk girth $(\mathrm{cm})$

Measured at fixed point $(30 \mathrm{~cm})$ from the soil surface.

Canopy volume $(m)$ :

Canopy volume $=\mathrm{HD}^{2} / 4$ where $\mathrm{H}=$ tree height and $\mathrm{D}=$ tree diameter (Wutscher, 1995) .

Leaf area $\left(\mathrm{cm}^{2}\right)$

In each season, 25 mature leaves were sampled randomly from each selected tree to determine leaf area $\left(\mathrm{cm}^{2}\right)$ which was estimated using digital planimeter (Planix 7).

\section{Flowering and fruiting measurements}

Percentage of perfect flowers

Percentage of perfect flowers/ tree $=$ No. of perfect flowers/ tree $\mathrm{x} 100 /$ Total number of flowers/ tree.

Egypt. J. Hort. Vol. 40, No.1 (2013) 
Percentage of initial fruit set

The number of hermaphrodite (perfect) flowers which succeeded to set fruits was also counted and fruit set (\%) was calculated.

Percentage of initial fruit set/ tree $=$ No. of set fruits/ tree $\times 100 /$ No. of perfect flowers/ tree

Yield/tree

All fruits were harvested as the recommended maturity standard outlined by El-Kassas et al. (1989) in two dates $\left(1^{\text {st }}\right.$ week of September \& mid October) in both seasons.

Total yield/tree was recorded as yield weight $(\mathrm{kg})$

Yield/feddan

Total yield/feddan was recorded as yield weight (ton)

Number of fruits/tree

Number of fruits was recorded in each of the investigated trees.

Fruit quality measurements

Fruit physical characteristics

Samples of 30 randomly fruits per treatment were selected for determining the following parameters:

a) Average fruit weight $(\mathrm{g})$

b) Peel thickness (mm)

c) Percentage of cracked fruits/ tree

Percentage of cracked fruits $=$ No. of cracked fruits/No. of total fruits x 100

d) Percentage of sunburned fruits/ tree

Percentage of sunburned fruits $=$ No. of sunburned fruits/No. of total fruits x 100

e) Percentage of marketable fruits/tree

Percentage of marketable fruits $=$ No. of total fruits - (No. of cracked fruits+ No. of sunburned fruits) $\times 100 /$ No. of total fruits

Fruit chemical characteristics

a) Total soluble solids percentage (TSS \%) was determined by hand rafractometer.

b) Acidity percentage was determined by titrating $5 \mathrm{ml}$ juice against 0.1 $\mathrm{NaOH}$ using phenolphthalene as an indicator.

The values of total acidity were expressed in grams of citric acid per 100 $\mathrm{ml}$ juice as described in (A. O. A. C., 1985).

c) Total soluble solids /acidity ratio was calculated.

d) Total sugars, were determined calorimetrically in sample of $5 \mathrm{ml}$ juice, according to the method described by Dubois et al., (1956). The amount of the estimated sugars in each sample was calculated in term of glucose.

e) Reducing Sugars.

f) Total anthocyanin content in fruit juice as described by Hsia et al., (1965). 
Statistical analysis

All data parameters studied were analyzed as a split plot in complete randomized blocks in factorial arrangement with three replications. All data were subjected to statistical analysis as described by Snedecor and Cochran (1990). The differences between the means were carried out using Duncan's Multiple Range Test (Duncan, 1955).

\section{Results and Discussion}

Vegetative growth measurements

Tree height $(m)$

Table 1 represents the effect of spacing and cultivars on tree height. Concerning the specific effect of spacing $(2.5 \times 2.5 \mathrm{~m})$, it gave significantly higher tree height in both seasons. In addition, Manfalouty formed greater tree height in both seasons. A significant interaction between spacing and cultivars was observed which gave the highest tree height with Manfalouty cv. grows in spacing $(2.5 \times 2.5 \mathrm{~m})$.

TABLE 1. Effect of planting density on tree height (m) of two pomegranate cultivars during (2010 and 2011) seasons.

\begin{tabular}{|c|c|c|c|c|c|c|}
\hline \multirow{2}{*}{ Treatments } & \multicolumn{3}{|c|}{2010} & \multicolumn{3}{c|}{2011} \\
\cline { 2 - 8 } & Manfalouty & $\begin{array}{c}\text { Nab El- } \\
\text { Gamal }\end{array}$ & Mean & Manfalouty & $\begin{array}{c}\text { Nab El- } \\
\text { Gamal }\end{array}$ & Mean \\
\hline $2.5 \times 2.5$ & $3.57 \mathrm{a}$ & $3.49 \mathrm{~b}$ & $3.53 \mathrm{~A}$ & $3.74 \mathrm{a}$ & $3.54 \mathrm{~b}$ & $3.64 \mathrm{~A}$ \\
\hline $4 \times 4$ & $3.48 \mathrm{~b}$ & $3.48 \mathrm{~b}$ & $3.48 \mathrm{~B}$ & $3.54 \mathrm{~b}$ & $3.37 \mathrm{c}$ & $3.46 \mathrm{~B}$ \\
\hline Mean & $3.52 \mathrm{~A}$ & $3.48 \mathrm{~B}$ & & $3.64 \mathrm{~A}$ & $3.46 \mathrm{~B}$ & \\
\hline
\end{tabular}

Means of each factor and their combinations in each season having the same letter/s are not significantly different at 5\% level using Duncan's Multiple Range Test.

\section{Trunk girths}

The presented results in Table 2 showed that, trunk girth increased by increasing planting density. Manfalouty cultivar recorded significantly higher trunk girth than Nab El-Gamal cultivar (especially in $2^{\text {nd }}$ season). A significant interaction between spacing and cultivars was observed with Manfalouty cv. grown on (4 x $4 \mathrm{~m})$ spacing which gave the highest trunk girths in both seasons. 
TABLE 2. Effect of planting density on tree girth $(\mathrm{cm})$ of two pomegranate cultivars during (2010 and 2011) seasons .

\begin{tabular}{|c|c|c|c|c|c|c|}
\hline \multirow{2}{*}{ Treatments } & \multicolumn{3}{|c|}{2010} & \multicolumn{3}{c|}{2011} \\
\cline { 2 - 7 } & Manfalouty & $\begin{array}{c}\text { Nab El- } \\
\text { Gamal }\end{array}$ & Mean & Manfalouty & $\begin{array}{c}\text { Nab El- } \\
\text { Gamal }\end{array}$ & Mean \\
\hline 2.5 X 2.5 & $38.13 \mathrm{~b}$ & $37.97 \mathrm{~b}$ & $38.05 \mathrm{~A}$ & $40.29 \mathrm{~b}$ & $39.48 \mathrm{c}$ & $39.89 \mathrm{~B}$ \\
\hline 4 X 4 & $39.03 \mathrm{a}$ & $38.28 \mathrm{~b}$ & $38.65 \mathrm{~A}$ & $41.53 \mathrm{a}$ & $40.63 \mathrm{~b}$ & $41.08 \mathrm{~A}$ \\
\hline Mean & $38.58 \mathrm{~A}$ & $38.12 \mathrm{~A}$ & & $40.91 \mathrm{~A}$ & $40.06 \mathrm{~B}$ & \\
\hline
\end{tabular}

Means of each factor and their combinations in each season having the same letter/s are not significantly different at 5\% level using Duncan's Multiple Range Test.

Canopy volume $(\mathrm{m})$

Table 3 clearly showed that, canopy volume (m) was increased significantly with increasing spacing (especially in $1^{\text {st }}$ season). Manfalouty trees recorded higher canopy volume (m) than Nab El-Gamal in second season. While, Nab ElGamal cv. grown in spacing ( 4 x $4 \mathrm{~m}$ ) gave the highest value in first season. On the other hand, Manfalouty cv. grows in both tested spacing recorded higher canopy volume $(\mathrm{m})$ than Nab El-Gamal in the $2^{\text {nd }}$ season.

TABLE 3. Effect of planting density on canopy volume (m) of two pomegranate cultivars during (2010 and 2011) seasons.

\begin{tabular}{|c|c|c|c|c|c|c|}
\hline \multirow{2}{*}{ Treatments } & \multicolumn{3}{|c|}{2010} & \multicolumn{3}{c|}{2011} \\
\cline { 2 - 7 } & Manfalouty & $\begin{array}{c}\text { Nab El- } \\
\text { Gamal }\end{array}$ & Mean & Manfalouty & $\begin{array}{c}\text { Nab El- } \\
\text { Gamal }\end{array}$ & Mean \\
\hline 2.5 X 2.5 & $10.57 \mathrm{c}$ & $10.26 \mathrm{~d}$ & $10.42 \mathrm{~B}$ & $15.25 \mathrm{a}$ & $13.86 \mathrm{~b}$ & $14.56 \mathrm{~A}$ \\
\hline 4 X 4 & $11.30 \mathrm{~b}$ & $11.66 \mathrm{a}$ & $11.48 \mathrm{~A}$ & $15.29 \mathrm{a}$ & $13.95 \mathrm{~b}$ & $14.62 \mathrm{~A}$ \\
\hline Mean & $10.94 \mathrm{~A}$ & $10.96 \mathrm{~A}$ & & $15.27 \mathrm{~A}$ & $13.90 \mathrm{~B}$ & \\
\hline
\end{tabular}

Means of each factor and their combinations in each season having the same letter/s are not significantly different at 5\% level using Duncan's Multiple Range Test.

Leaf area $\left(\mathrm{cm}^{2}\right)$

Data in Table 4 didn't appear any significant differences between the investigated treatments or cultivars.

TABLE 4. Effect of planting density on leaf area $\left(\mathrm{cm}^{2}\right)$ of two pomegranate cultivars during (2010 and 2011) seasons.

\begin{tabular}{|c|c|c|c|c|c|c|}
\hline \multirow{2}{*}{ Treatments } & \multicolumn{3}{|c|}{2010} & \multicolumn{3}{c|}{2011} \\
\cline { 2 - 7 } & Manfalouty & $\begin{array}{c}\text { Nab El- } \\
\text { Gamal }\end{array}$ & Mean & Manfalouty & $\begin{array}{c}\text { Nab El- } \\
\text { Gamal }\end{array}$ & Mean \\
\hline $2.5 \times 2.5$ & $5.68 \mathrm{a}$ & $5.60 \mathrm{a}$ & $5.64 \mathrm{~A}$ & $5.83 \mathrm{ab}$ & $5.75 \mathrm{~b}$ & $5.79 \mathrm{~A}$ \\
\hline $4 \times 4$ & $5.70 \mathrm{a}$ & $5.70 \mathrm{a}$ & $5.70 \mathrm{~A}$ & $6.01 \mathrm{a}$ & $5.98 \mathrm{ab}$ & $5.99 \mathrm{~A}$ \\
\hline Mean & $5.69 \mathrm{~A}$ & $5.65 \mathrm{~A}$ & & $5.92 \mathrm{~A}$ & $5.87 \mathrm{~A}$ & \\
\hline
\end{tabular}

Means of each factor and their combinations in each season having the same letter/s are not significantly different at 5\% level using Duncan's Multiple Range Test. 
Increasing of number of trees per unit area may affect in increasing of vertical growth, so increasing in tree height and reducing trunk girth and volume canopy.

These results are in harmony with the finding of Nasir et al. (2006) in citrus who noticed that, trees planted at $2 \times 5 \mathrm{~m}$ were the tallest, but the canopy diameter, stem girth and volume of trees planted at $5 \times 5 \mathrm{~m}$ were the largest. Also, in banana, the closer spacing recorded maximum plant height while, the wider spacing recorded minimum plant height. Increase leaf area in wider spacing may be due to less competition for moisture and sunlight (Athani et al., 2009). However, High planting density (i.e. closer spacing) caused reduction in vegetative growth of mango trees (Ferreira de Sousa et al., 2012).

\section{Flowering and fruiting measurements}

Percentage of perfect flowers

Table 5 clearly showed that, perfect flowers (\%) were increased with treatment ( 4 x $4 \mathrm{~m}$ ) spacing during the both of seasons. While, didn't appear any significant differences between both investigated varieties. In addition, Manfalouty cv. grown in spacing $(4 \mathrm{x} 4 \mathrm{~m})$ recorded the highest perfect flowers $(\%)$ in both seasons.

TABLE 5. Effect of planting density on percentage of perfect flowers of two pomegranate cultivars during (2010 and 2011$)$ seasons.

\begin{tabular}{|c|c|c|c|c|c|c|}
\hline \multirow{2}{*}{ Treatments } & \multicolumn{3}{|c|}{2010} & \multicolumn{3}{c|}{2011} \\
\cline { 2 - 7 } & Manfalouty & $\begin{array}{c}\text { Nab El- } \\
\text { Gamal }\end{array}$ & Mean & Manfalouty & $\begin{array}{c}\text { Nab El- } \\
\text { Gamal }\end{array}$ & Mean \\
\hline $2.5 \times 2.5$ & $29.82 \mathrm{~b}$ & $28.11 \mathrm{c}$ & $28.97 \mathrm{~B}$ & $30.02 \mathrm{bc}$ & $29.04 \mathrm{c}$ & $29.53 \mathrm{~B}$ \\
\hline $4 \times 4$ & $32.13 \mathrm{a}$ & $30.59 \mathrm{~b}$ & $31.36 \mathrm{~A}$ & $33.19 \mathrm{a}$ & $31.00 \mathrm{~b}$ & $32.09 \mathrm{~A}$ \\
\hline Mean & $30.97 \mathrm{~A}$ & $29.35 \mathrm{~A}$ & & $31.60 \mathrm{~A}$ & $30.02 \mathrm{~A}$ & \\
\hline
\end{tabular}

Means of each factor and their combinations in each season having the same letter/s are not significantly different at 5\% level using Duncan's Multiple Range Test.

\section{Percentage of Initial fruit set}

Table 6 shows that, treatment $(4 \times 4 \mathrm{~m})$ resulted in higher significant initial fruit set $(\%)$ in both seasons of the study compared to $(2.5 \times 2.5 \mathrm{~m})$ treatment. In addition, Manfalouty formed the greatest initial fruit set in the $2^{\text {nd }}$ season of study. A significant interaction between spacing and cultivars was observed by initial fruit set (\%) of Manfalouty cv. grown in spacing (4 x $4 \mathrm{~m})$ which gave higher values in both seasons. 
TABLE 6. Effect of planting density on initial fruit set of two pomegranate cultivars during (2010 and 2011) seasons.

\begin{tabular}{|c|c|c|c|c|c|c|}
\hline \multirow{2}{*}{ Treatments } & \multicolumn{3}{|c|}{2010} & \multicolumn{3}{c|}{2011} \\
\cline { 2 - 7 } & Manfalouty & $\begin{array}{c}\text { Nab El- } \\
\text { Gamal }\end{array}$ & Mean & Manfalouty & $\begin{array}{c}\text { Nab El- } \\
\text { Gamal }\end{array}$ & Mean \\
\hline 2.5 X 2.5 & $69.60 \mathrm{~b}$ & $71.89 \mathrm{ab}$ & $70.74 \mathrm{~B}$ & $71.32 \mathrm{c}$ & $70.70 \mathrm{c}$ & $71.01 \mathrm{~B}$ \\
\hline 4 X 4 & $76.48 \mathrm{a}$ & $73.51 \mathrm{ab}$ & $74.99 \mathrm{~A}$ & $77.26 \mathrm{a}$ & $74.16 \mathrm{~b}$ & $75.71 \mathrm{~A}$ \\
\hline Mean & $73.04 \mathrm{~A}$ & $72.70 \mathrm{~A}$ & & $74.29 \mathrm{~A}$ & $72.43 \mathrm{~B}$ & \\
\hline
\end{tabular}

Means of each factor and their combinations in each season having the same letter/s are not significantly different at 5\% level using Duncan's Multiple Range Test.

\section{Yield/tree ( $\mathrm{kg}$ )}

Table 7 clearly showed that, yield/tree was increased with increasing the spacing during the two seasons of study. Manfalouty recorded significantly higher yield/tree than Nab El-Gamal in both seasons. In addition, Manfalouty cv. grows in spacing $(4 \times 4 \mathrm{~m})$ recorded higher yield/tree than Nab El-Gamal in both seasons.

TABLE 7. Effect of planting density on yield/tree (kg) of two pomegranate cultivars during (2010 and 2011) seasons.

\begin{tabular}{|c|c|c|c|c|c|c|}
\hline \multirow{2}{*}{ Treatments } & \multicolumn{3}{|c|}{2010} & \multicolumn{3}{c|}{2011} \\
\cline { 2 - 7 } & Manfalouty & $\begin{array}{c}\text { Nab El- } \\
\text { Gamal }\end{array}$ & Mean & Manfalouty & $\begin{array}{c}\text { Nab El- } \\
\text { Gamal }\end{array}$ & Mean \\
\hline 2.5 X 2.5 & $16.94 \mathrm{c}$ & $14.37 \mathrm{~d}$ & $15.66 \mathrm{~B}$ & $21.10 \mathrm{c}$ & $18.48 \mathrm{~d}$ & $19.79 \mathrm{~B}$ \\
\hline 4 X 4 & $27.38 \mathrm{a}$ & $22.82 \mathrm{~b}$ & $25.10 \mathrm{~A}$ & $37.05 \mathrm{a}$ & $32.02 \mathrm{~b}$ & $34.53 \mathrm{~A}$ \\
\hline Mean & $22.16 \mathrm{~A}$ & $18.59 \mathrm{~B}$ & & $29.08 \mathrm{~A}$ & $25.25 \mathrm{~B}$ & \\
\hline
\end{tabular}

Means of each factor and their combinations in each season having the same letter/s are not significantly different at 5\% level using Duncan’s Multiple Range Test.

Yield/Fedden (Ton)

Table 8 clearly showed, that yield/Fed. (Ton) decreased with increasing the spacing. Manfalouty recorded significantly higher yield/ Fed. (Ton) than Nab ElGamal in both seasons. In addition, Manfalouty cv. grows in spacing $(2.5 \times 2.5$ $\mathrm{m}$ ) recorded the maximum yield/Fed. in both seasons of study.

TABLE 8. Effect of planting density on yield/Feddan (Ton) of two pomegranate cultivars during (2010 and 2011) seasons.

\begin{tabular}{|c|c|c|c|c|c|c|}
\hline \multirow{2}{*}{ Treatments } & \multicolumn{3}{|c|}{$\mathbf{2 0 1 0}$} & \multicolumn{3}{c|}{2011} \\
\cline { 2 - 7 } & Manfalouty & $\begin{array}{c}\text { Nab El- } \\
\text { Gamal }\end{array}$ & Mean & Manfalouty & $\begin{array}{c}\text { Nab El- } \\
\text { Gamal }\end{array}$ & Mean \\
\hline 2.5 X 2.5 & $11.38 \mathrm{a}$ & $9.66 \mathrm{~b}$ & $10.52 \mathrm{~A}$ & $14.18 \mathrm{a}$ & $12.42 \mathrm{~b}$ & $13.30 \mathrm{~A}$ \\
\hline 4 X 4 & $7.17 \mathrm{c}$ & $5.98 \mathrm{~d}$ & $6.57 \mathrm{~B}$ & $9.71 \mathrm{c}$ & $8.39 \mathrm{~d}$ & $9.05 \mathrm{~B}$ \\
\hline Mean & $9.28 \mathrm{~A}$ & $7.82 \mathrm{~B}$ & & $11.94 \mathrm{~A}$ & $10.40 \mathrm{~B}$ & \\
\hline
\end{tabular}

Means of each factor and their combinations in each season having the same letter/s are not significantly different at 5\% level using Duncan's Multiple Range Test. 


\section{Number of fruits/tree}

Table 9 clearly showed that, number of fruits/tree increased with increasing the spacing during the two seasons. Manfalouty recorded higher number of fruits/tree than Nab El-Gamal in both seasons. On the other hand, Manfalouty cv. grows in spacing $(4 \times 4 \mathrm{~m})$ recorded the highest number of fruits during the two seasons of the study.

TABLE 9. Effect of planting density on number of fruits of two pomegranate cultivars during (2010 and 2011) seasons.

\begin{tabular}{|c|c|c|c|c|c|c|}
\hline \multirow{2}{*}{ Treatments } & \multicolumn{3}{|c|}{2010} & \multicolumn{3}{c|}{2011} \\
\cline { 2 - 7 } & Manfalouty & $\begin{array}{c}\text { Nab } \\
\text { El- } \\
\text { Gamal }\end{array}$ & Mean & Manfalouty & $\begin{array}{c}\text { Nab El- } \\
\text { Gamal }\end{array}$ & Mean \\
\hline $2.5 \times 2.5$ & $51.50 \mathrm{c}$ & $44.21 \mathrm{~d}$ & $47.85 \mathrm{~B}$ & $51.60 \mathrm{c}$ & $47.03 \mathrm{~d}$ & $49.31 \mathrm{~B}$ \\
\hline $4 \mathrm{X} 4$ & $82.27 \mathrm{a}$ & $68.77 \mathrm{~b}$ & $75.52 \mathrm{~A}$ & $85.62 \mathrm{a}$ & $76.98 \mathrm{~b}$ & $81.30 \mathrm{~A}$ \\
\hline Mean & $66.88 \mathrm{~A}$ & $56.49 \mathrm{~B}$ & & $68.61 \mathrm{~A}$ & $62.00 \mathrm{~B}$ & \\
\hline
\end{tabular}

Means of each factor and their combinations in each season having the same letter/s are not significantly different at 5\% level using Duncan's Multiple Range Test.

Generally, wide spacing resulted in increasing in trees volume so, increasing number of flowering on tree, initial fruit set $(\%)$, number of fruits/tree and yield /tree. While the close spacing caused increasing in number of tree/feddan. So, increasing in yield/feddan by multiplication of (Yield/tree x No. of trees/Feddan).

Our results are in agreement with Bassal, (2009) in citrus who found that, initial yields per tree from planting spacing of $2 \times 5 \mathrm{~m}$ were lower than those from the wide spacing, but the yield per feddan from trees planted at $2 \times 5 \mathrm{~m}$ was greater than those planted at $5 \times 5 \mathrm{~m}$. Also, Bryla and Strik, (2007) in blueberry confirmed that, planting at high density significantly reduced yield of individual plants but significantly increased yield per hectare. Crop load was increased in kiwifruit orchards by using the close spacing compared with wide spacing in the first 5 years after planting (Testolin, 1990). The closer spacing in banana recorded maximum yield, while the wider spacing recorded minimum yield, it is determined by various vegetative and reproductive characters. The yield per hectare was significantly higher in high density population or closer spacing. This can be attributed to increase in plant population per unit area, but the higher bunch weight observed in wider spacing can partially compensated by higher yields obtained in closer spacing (Athani et al., 2009). On the other hand, high density planting caused decreasing in the percentage of flowering, fruit yield per plant and per area (Ferreira de Sousa et al., 2012). Also, tree density affects both interception and distribution of light, and influences flower density (Wertheim, 1985; and Callesen \& Wagenmakers, 1989).

Egypt. J. Hort. Vol. 40, No.1 (2013) 
Fruit Quality Measurements

Fruit Physical Characteristics

(a) Fruit weight $(\mathrm{g})$ : Table 10 clearly showed that, fruit weight $(\mathrm{g})$ increased with increasing the spacing during the two seasons of the study. Manfalouty recorded significantly higher fruit weight $(\mathrm{g})$ than Nab El-Gamal (in $2^{\text {nd }}$ season). In addition, Manfalouty cv. grows in spacing $(4 \mathrm{x} 4 \mathrm{~m})$ recorded the highest fruit weight $(\mathrm{g})$ in both seasons.

TABLE 10. Effect of planting density on fruit weight (g) of two pomegranate cultivars during (2010 and 2011) seasons.

\begin{tabular}{|c|c|c|c|c|c|c|}
\hline \multirow{2}{*}{ Treatments } & \multicolumn{3}{|c|}{2010} & \multicolumn{3}{c|}{2011} \\
\cline { 2 - 7 } & Manfalouty & $\begin{array}{c}\text { Nab El- } \\
\text { Gamal }\end{array}$ & Mean & Manfalouty & $\begin{array}{c}\text { Nab El- } \\
\text { Gamal }\end{array}$ & Mean \\
\hline 2.5 X 2.5 & $328.9 \mathrm{~b}$ & $325.0 \mathrm{c}$ & $326.9 \mathrm{~B}$ & $408.9 \mathrm{~b}$ & $392.9 \mathrm{c}$ & $400.9 \mathrm{~B}$ \\
\hline 4 X 4 & $332.8 \mathrm{a}$ & $331.8 \mathrm{a}$ & $332.3 \mathrm{~A}$ & $432.7 \mathrm{a}$ & $415.9 \mathrm{~b}$ & $424.3 \mathrm{~A}$ \\
\hline Mean & $330.8 \mathrm{~A}$ & $328.4 \mathrm{~A}$ & & $420.8 \mathrm{~A}$ & $404.4 \mathrm{~B}$ & \\
\hline
\end{tabular}

Means of each factor and their combinations in each season having the same letter/s are not significantly different at 5\% level using Duncan's Multiple Range Test.

(b) Peel thickness: The obtained results in Table 11 clearly show that, peel thickness resulted in higher $(2.5 \times 2.5 \mathrm{~m})$ than $(4 \times 4 \mathrm{~m})$ treatment. Peel thickness was significantly greater in Manfalouty cv. compared to Nab El-Gamal cv. in both seasons. In addition, Manfalouty cv. grows in spacing $(2.5 \times 2.5 \mathrm{~m})$ recorded the highest values of peel thickness in both of seasons.

TABLE 11. Effect of planting density on peel thickness ( $\mathrm{mm}$ ) of two pomegranate cultivars during (2010 and 2011) seasons.

\begin{tabular}{|c|c|c|c|c|c|c|}
\hline \multirow{2}{*}{ Treatments } & \multicolumn{3}{|c|}{2010} & \multicolumn{3}{c|}{2011} \\
\cline { 2 - 7 } & Manfalouty & $\begin{array}{c}\text { Nab El- } \\
\text { Gamal }\end{array}$ & Mean & Manfalouty & $\begin{array}{c}\text { Nab El- } \\
\text { Gamal }\end{array}$ & Mean \\
\hline 2.5 X 2.5 & $4.88 \mathrm{a}$ & $4.58 \mathrm{bc}$ & $4.73 \mathrm{~A}$ & $4.77 \mathrm{a}$ & $4.59 \mathrm{~b}$ & $4.68 \mathrm{~A}$ \\
\hline 4 X 4 & $4.63 \mathrm{~b}$ & $4.48 \mathrm{c}$ & $4.56 \mathrm{~B}$ & $4.57 \mathrm{~b}$ & $4.50 \mathrm{~b}$ & $4.53 \mathrm{~B}$ \\
\hline Mean & $4.75 \mathrm{~A}$ & $4.53 \mathrm{~B}$ & & $4.67 \mathrm{~A}$ & $4.54 \mathrm{~B}$ & \\
\hline
\end{tabular}

Means of each factor and their combinations in each season having the same letter/s are not significantly different at 5\% level using Duncan's Multiple Range Test.

(c) Percentage of cracked fruits: In Table 12 it is clear that, $(4 \times 4 \mathrm{~m})$ treatment significantly increased fruit cracking as compared with $(2.5 \times 2.5 \mathrm{~m})$ treatment. Nab El-Gamal recorded significantly the higher fruit cracking than Manfalouty in both seasons. Moreover, cracked fruits (\%) in both investigated cvs. decreased by decreasing plant spacing. 
TABLE 12. Effect of planting density on fruit cracking (\%) of two pomegranate cultivars during (2010 and 2011) seasons.

\begin{tabular}{|c|c|c|c|c|c|c|}
\hline \multirow{2}{*}{ Treatments } & \multicolumn{3}{|c|}{2010} & \multicolumn{3}{c|}{2011} \\
\cline { 2 - 7 } & Manfalouty & $\begin{array}{c}\text { Nab El- } \\
\text { Gamal }\end{array}$ & Mean & Manfalouty & $\begin{array}{c}\text { Nab El- } \\
\text { Gamal }\end{array}$ & Mean \\
\hline $2.5 \times 2.5$ & $3.20 \mathrm{c}$ & $4.18 \mathrm{~b}$ & $3.69 \mathrm{~B}$ & $3.11 \mathrm{c}$ & $4.31 \mathrm{~b}$ & $3.71 \mathrm{~B}$ \\
\hline $4 \mathrm{X} 4$ & $5.22 \mathrm{a}$ & $5.54 \mathrm{a}$ & $5.38 \mathrm{~A}$ & $6.22 \mathrm{a}$ & $6.54 \mathrm{a}$ & $6.38 \mathrm{~A}$ \\
\hline Mean & $4.21 \mathrm{~A}$ & $4.86 \mathrm{~A}$ & & $4.66 \mathrm{~B}$ & $5.43 \mathrm{~A}$ & \\
\hline
\end{tabular}

Means of each factor and their combinations in each season having the same letter/s are not significantly different at 5\% level using Duncan's Multiple Range Test.

(d) Percentage of sunburned fruits: Data presented in Table 13 showed that the greatest percentages of sunburned fruits were obtained by increasing spacing ( 4 x $4 \mathrm{~m}$ ) during both seasons. Nab El-Gamal gave the highest significant value compared to Manfalouty ( $2^{\text {nd }}$ season). In addition, Nab El-Gamal cv. grows in spacing $(4 \times 4 \mathrm{~m})$ recorded the highest percentage of sunburned fruits in both seasons.

TABLE 13. Effect of planting density on sunburned fruits (\%) of two pomegranate cultivars during (2010 and 2011) seasons.

\begin{tabular}{|c|c|c|c|c|c|c|}
\hline \multirow{2}{*}{ Treatments } & \multicolumn{3}{|c|}{2010} & \multicolumn{3}{c|}{2011} \\
\cline { 2 - 7 } & Manfalouty & $\begin{array}{c}\text { Nab El- } \\
\text { Gamal }\end{array}$ & Mean & Manfalouty & $\begin{array}{c}\text { Nab El- } \\
\text { Gamal }\end{array}$ & Mean \\
\hline $2.5 \times 2.5$ & $10.21 \mathrm{~d}$ & $11.78 \mathrm{c}$ & $11.00 \mathrm{~B}$ & $8.87 \mathrm{~d}$ & $9.65 \mathrm{c}$ & $9.26 \mathrm{~B}$ \\
\hline $4 \mathrm{X} 4$ & $13.26 \mathrm{~b}$ & $14.65 \mathrm{a}$ & $13.96 \mathrm{~A}$ & $13.39 \mathrm{~b}$ & $15.55 \mathrm{a}$ & $14.47 \mathrm{~A}$ \\
\hline Mean & $11.73 \mathrm{~A}$ & $13.22 \mathrm{~A}$ & & $11.13 \mathrm{~B}$ & $12.60 \mathrm{~A}$ & \\
\hline
\end{tabular}

Means of each factor and their combinations in each season having the same letter/s are not significantly different at 5\% level using Duncan's Multiple Range Test.

(e) Marketable fruits (\%): The obtained results in Table 14 clearly show that, marketable fruits resulted in higher percentage in $(2.5 \times 2.5 \mathrm{~m})$ than $(4 \times 4 \mathrm{~m})$ treatment. It was significantly greater in Manfalouty cv. compared to Nab ElGamal cv. in both seasons. In addition, Manfalouty cv. grows in spacing $(2.5 \mathrm{x}$ $2.5 \mathrm{~m}$ ) recorded the highest percentage of marketable fruits in both seasons.

TABLE 14. Effect of planting density on marketable fruits of two pomegranate cultivars during (2010 and 2011) seasons.

\begin{tabular}{|c|c|c|c|c|c|c|}
\hline \multirow{2}{*}{ Treatments } & \multicolumn{3}{|c|}{2010} & \multicolumn{3}{c|}{2011} \\
\cline { 2 - 7 } & Manfalouty & $\begin{array}{c}\text { Nab El- } \\
\text { Gamal }\end{array}$ & Mean & Manfalouty & $\begin{array}{c}\text { Nab El- } \\
\text { Gamal }\end{array}$ & Mean \\
\hline $2.5 \times 2.5$ & $86.59 \mathrm{a}$ & $84.04 \mathrm{~b}$ & $85.31 \mathrm{~A}$ & $88.02 \mathrm{a}$ & $86.04 \mathrm{~b}$ & $87.03 \mathrm{~A}$ \\
\hline $4 \mathrm{X} 4$ & $81.52 \mathrm{c}$ & $79.81 \mathrm{~d}$ & $80.66 \mathrm{~B}$ & $80.39 \mathrm{c}$ & $77.91 \mathrm{~d}$ & $79.15 \mathrm{~B}$ \\
\hline Mean & $84.05 \mathrm{~A}$ & $81.92 \mathrm{~B}$ & & $84.20 \mathrm{~A}$ & $81.97 \mathrm{~B}$ & \\
\hline
\end{tabular}

Means of each factor and their combinations in each season having the same letter/s are no significantly different at 5\% level using Duncan's Multiple Range Test.

It can be explained by the obtained results of this study that, increasing of vegetative growth in the wider spacing leads to increasing in fruit weight and

Egypt. J. Hort. Vol. 40, No.1 (2013) 
fruit cracking, however, these fruits were exposed to high light effect that caused sunburn damage. However, reducing in fruit cracking with the close spacing may be related to increasing of peel thickness as it was be clear from our obtained results.

These results were similar with those obtained by Nasir et al. (2006), who noticed that, highest fruit weight was observed in the widest spacing and minimum values of these were in close spacing. Also, Goswami et al. (1993) reported that quality of citrus fruits under high density planting, though fruits were smaller. Moreover, high fruit quality of apple can be achieved with a highdensity orchard when the orchard has good light distribution throughout the tree canopy and there is a balance between vegetative growth and cropping (Robinson, 1997). While, Donadio et al. (1995) in Pera oranges reported that, fruit size and quality were not influenced by different plant spacing. Also, in mango trees, high density planting had little influence on fruit quality (Ferreira de Sousa et al. 2012).

\section{Fruit chemical characteristics}

a) Total soluble solids (\%): Table 15 shows that, treatment $(4 \times 4 \mathrm{~m})$ results in the highest significant TSS (\%) in both seasons of the study compared to treatment $(2.5 \times 2.5 \mathrm{~m})$. In addition, Manfalouty formed the greatest TSS $(\boldsymbol{\%})$ in both seasons of study. A significant interaction between spacing and cultivars was observed in TSS (\%) when Manfalouty cv. grew in spacing $(4 \times \mathrm{x})$ gave the highest values in both seasons of study.

TABLE 15. Effect of planting density on total soluble solids (\%) of two pomegranate cultivars during (2010 and 2011) seasons.

\begin{tabular}{|c|c|c|c|c|c|c|}
\hline \multirow{2}{*}{ Treatments } & \multicolumn{3}{|c|}{2010} & \multicolumn{3}{c|}{2011} \\
\cline { 2 - 7 } & Manfalouty & $\begin{array}{c}\text { Nab El- } \\
\text { Gamal }\end{array}$ & Mean & Manfalouty & $\begin{array}{c}\text { Nab El- } \\
\text { Gamal }\end{array}$ & Mean \\
\hline $2.5 \times 2.5$ & $15.41 \mathrm{~b}$ & $14.60 \mathrm{c}$ & $15.01 \mathrm{~B}$ & $15.70 \mathrm{~b}$ & $15.08 \mathrm{c}$ & $15.39 \mathrm{~B}$ \\
\hline $4 \mathrm{X} 4$ & $15.80 \mathrm{a}$ & $15.24 \mathrm{~b}$ & $15.52 \mathrm{~A}$ & $16.38 \mathrm{a}$ & $15.60 \mathrm{~b}$ & $15.99 \mathrm{~A}$ \\
\hline Mean & $15.61 \mathrm{~A}$ & $14.92 \mathrm{~B}$ & & $16.04 \mathrm{~A}$ & $15.34 \mathrm{~B}$ & \\
\hline
\end{tabular}

Means of each factor and their combinations in each season having the same letter/s are not significantly different at 5\% level using Duncan's Multiple Range Test.

b) Acidity (\%): Data in Table 16 didn't appear any significant differences regarding acidity $(\%)$ between the investigated treatments or varieties. 
TABLE 16. Effect of planting density on Acidity (\%) of two pomegranate cultivars during (2010 and 2011) seasons.

\begin{tabular}{|c|c|c|c|c|c|c|}
\hline \multirow{2}{*}{ Treatments } & \multicolumn{3}{|c|}{2010} & \multicolumn{3}{c|}{2011} \\
\cline { 2 - 7 } & Manfalouty & $\begin{array}{c}\text { Nab El- } \\
\text { Gamal }\end{array}$ & Mean & Manfalouty & $\begin{array}{c}\text { Nab El- } \\
\text { Gamal }\end{array}$ & Mean \\
\hline 2.5 X 2.5 & $1.65 \mathrm{a}$ & $1.60 \mathrm{a}$ & $1.62 \mathrm{~A}$ & $1.41 \mathrm{a}$ & $1.39 \mathrm{a}$ & $1.40 \mathrm{~A}$ \\
\hline 4 X 4 & $1.58 \mathrm{a}$ & $1.57 \mathrm{a}$ & $1.57 \mathrm{~A}$ & $1.39 \mathrm{a}$ & $1.37 \mathrm{a}$ & $1.38 \mathrm{~A}$ \\
\hline Mean & $1.61 \mathrm{~A}$ & $1.58 \mathrm{~A}$ & & $1.40 \mathrm{~A}$ & $1.38 \mathrm{~A}$ & \\
\hline
\end{tabular}

Means of each factor and their combinations in each season having the same letter/s are not significantly different at 5\% level using Duncan's Multiple Range Test.

c) Total soluble solids/acidity ratio: Table 17 clearly showed that, TSS/acidity was increased with treatment $(4 \mathrm{x} 4 \mathrm{~m})$ spacing during the both of seasons. Nab El-Gamal recorded the higher TSS/acidity ratio than Manfalouty in both seasons. In addition, Nab El-Gamal cv. grows in spacing $(4 \mathrm{x} 4 \mathrm{~m})$ recorded the highest ratio of TSS/acidity in both of the seasons.

TABLE 17. Effect of planting density on TSS/acidity ratio of two pomegranate cultivars during (2010 and 2011) seasons.

\begin{tabular}{|c|c|c|c|c|c|c|}
\hline \multirow{2}{*}{ Treatments } & \multicolumn{3}{|c|}{2010} & \multicolumn{3}{c|}{2011} \\
\cline { 2 - 7 } & Manfalouty & $\begin{array}{c}\text { Nab El- } \\
\text { Gamal }\end{array}$ & Mean & Manfalouty & $\begin{array}{c}\text { Nab El- } \\
\text { Gamal }\end{array}$ & Mean \\
\hline 2.5 X 2.5 & $9.13 \mathrm{~d}$ & $9.34 \mathrm{c}$ & $9.23 \mathrm{~B}$ & $10.85 \mathrm{~d}$ & $11.13 \mathrm{c}$ & $10.99 \mathrm{~B}$ \\
\hline 4 X 4 & $9.71 \mathrm{~b}$ & $10.0 \mathrm{a}$ & $9.85 \mathrm{~A}$ & $11.39 \mathrm{~b}$ & $11.78 \mathrm{a}$ & $11.59 \mathrm{~A}$ \\
\hline Mean & $9.42 \mathrm{~B}$ & $9.67 \mathrm{~A}$ & & $11.12 \mathrm{~B}$ & $11.45 \mathrm{~A}$ & \\
\hline
\end{tabular}

Means of each factor and their combinations in each season having the same letter/s are not significantly different at 5\% level using Duncan's Multiple Range Test.

d) Total sugars (\%): According to the results in Table 18 it can be noticed that, spacing $(4 \times 4 \mathrm{~m})$ significantly increased the total sugars than $(2.5 \times 2.5 \mathrm{~m})$ treatment in both 2010 and 2011 seasons. Total sugars were significantly greater in Manfalouty cv. compared to Nab El-Gamal during the two seasons.

TABLE 18. Effect of planting density on total sugars (\%) of two pomegranate cultivars during (2010 and 2011) seasons.

\begin{tabular}{|c|c|c|c|c|c|c|}
\hline \multirow{2}{*}{ Treatments } & \multicolumn{3}{|c|}{2010} & \multicolumn{3}{c|}{2011} \\
\cline { 2 - 7 } & Manfalouty & $\begin{array}{c}\text { Nab El- } \\
\text { Gamal }\end{array}$ & Mean & Manfalouty & $\begin{array}{c}\text { Nab El- } \\
\text { Gamal }\end{array}$ & Mean \\
\hline 2.5 X 2.5 & $11.85 \mathrm{~b}$ & $10.85 \mathrm{c}$ & $11.35 \mathrm{~B}$ & $12.69 \mathrm{c}$ & $12.03 \mathrm{~d}$ & $12.36 \mathrm{~B}$ \\
\hline 4 X 4 & $12.69 \mathrm{a}$ & $12.38 \mathrm{a}$ & $12.53 \mathrm{~A}$ & $13.47 \mathrm{a}$ & $13.05 \mathrm{~b}$ & $13.26 \mathrm{~A}$ \\
\hline Mean & $12.69 \mathrm{~A}$ & $11.61 \mathrm{~B}$ & & $13.08 \mathrm{~A}$ & $12.54 \mathrm{~B}$ & \\
\hline
\end{tabular}

Means of each factor and their combinations in each season having the same letter/s are not significantly different at 5\% level using Duncan's Multiple Range Test. 
e) Reducing sugars (\%): Table 19 shows that treatment $(4 \times 4 \mathrm{~m})$ results in the highest significant reducing sugars $(\%)$ in both seasons of the study compared to treatment $(2.5 \times 2.5 \mathrm{~m})$. In addition, Manfalouty formed the greatest reducing Sugar (\%) in first seasons of the study.

TABLE 19. Effect of planting density on reducing sugars (\%) of two pomegranate cultivars during (2010 and 2011) seasons .

\begin{tabular}{|c|c|c|c|c|c|c|}
\hline \multirow{2}{*}{ Treatments } & \multicolumn{3}{|c|}{2010} & \multicolumn{3}{c|}{2011} \\
\cline { 2 - 7 } & Manfalouty & $\begin{array}{c}\text { Nab El- } \\
\text { Gamal }\end{array}$ & Mean & Manfalouty & $\begin{array}{c}\text { Nab El- } \\
\text { Gamal }\end{array}$ & Mean \\
\hline 2.5 X 2.5 & $11.86 \mathrm{~b}$ & $10.85 \mathrm{c}$ & $11.35 \mathrm{~B}$ & $11.60 \mathrm{c}$ & $11.23 \mathrm{~d}$ & $11.41 \mathrm{~B}$ \\
\hline 4 X 4 & $12.69 \mathrm{a}$ & $12.33 \mathrm{a}$ & $12.51 \mathrm{~A}$ & $12.27 \mathrm{~b}$ & $12.74 \mathrm{a}$ & $12.50 \mathrm{~A}$ \\
\hline Mean & $12.28 \mathrm{~A}$ & $11.59 \mathrm{~B}$ & & $11.93 \mathrm{~A}$ & $11.98 \mathrm{~A}$ & \\
\hline
\end{tabular}

Means of each factor and their combinations in each season having the same letter/s are no significantly different at 5\% level using Duncan's Multiple Range Test.

e) Anthocyanin (\%): Data in Table 20 didn't appear any significant differences between the investigated treatments or varieties.

TABLE 20. Effect of planting density on Anthocyanin (\%) of two pomegranate cultivars during (2010 and 2011) seasons.

\begin{tabular}{|c|c|c|c|c|c|c|}
\hline \multirow{2}{*}{ Treatments } & \multicolumn{3}{|c|}{2010} & \multicolumn{3}{c|}{2011} \\
\cline { 2 - 7 } & Manfalouty & $\begin{array}{c}\text { Nab El- } \\
\text { Gamal }\end{array}$ & Mean & Manfalouty & $\begin{array}{c}\text { Nab El- } \\
\text { Gamal }\end{array}$ & Mean \\
\hline 2.5 X 2.5 & $0.353 \mathrm{a}$ & $0.341 \mathrm{a}$ & $0.347 \mathrm{~A}$ & $0.345 \mathrm{a}$ & $0.338 \mathrm{a}$ & $0.342 \mathrm{~A}$ \\
\hline 4 X 4 & $0.344 \mathrm{a}$ & $0.340 \mathrm{a}$ & $0.342 \mathrm{~A}$ & $0.337 \mathrm{a}$ & $0.330 \mathrm{a}$ & $0.337 \mathrm{~A}$ \\
\hline Mean & $0.348 \mathrm{~A}$ & $0.340 \mathrm{~A}$ & & $0.341 \mathrm{~A}$ & $0.334 \mathrm{~A}$ & \\
\hline
\end{tabular}
significantly different at 5\% level using Duncan's Multiple Range Test.

Total and reduced sugars (\%) reported as a high values with the wide spacing, it might related to the growth increasing and nutrient uptake and it was reflected on fruit sugars content. Also, total soluble solids (\%) increased in wide spacing related to increasing of total sugars.

All these results were in harmony with those that obtained by Nasir et al. (2006) in citrus who noticed that, TSS and TSS/acidity ratio was observed highly in the widest spacing and minimum values of these were close spacing. TSS/acidity ratio was maximum in highest spacing which decreased with decrease in planting space and minimum ratio was in the closest spacing. Acidity and TSS in fruit are responsible for this ratio. Increase in acidity or decrease in TSS affect the TSS/acidity ratio. 
Also, Singh et al., (2005) in guava reported that, widest spacing $(6.0 \times 6.0 \mathrm{~m}$ and $3.0 \times 6.0 \mathrm{~m}$ ) produced fruits of more better TSS and total sugars than the closest spacing $(1.5 \times 3.0 \mathrm{~m})$. Meanwhile, Chadha $(2001)$ noticed that plants which planted at close distance produced fruit of inferior quality.

\section{Conclusion}

Generally, under the same conditions of the present study we may recommend that, Manfalouty pomegranate cultivar could be planted under the level of plant spacing $(2.5 \times 2.5 \mathrm{~m})$.

\section{References}

Association of Official Agricultural Chemists (A.O.A.C.) (1985) Official Methods of Analysis, $15^{\text {th }}$ ed. Published by A.O.A.C. Washington, D.C., USA.

Abo-Taleb, S.A., Noman, V.F. and Sari El Deen, S. (1998) Growth of pomegranate transplants as affected by different water regimes. Annals of Agric. Sc., Moshtohor, 36 (2),1073-1091.

Abouelwafa, M. (2006) Effect of some treatments on improving pomegranate fruit quality. $P h D$., Cairo University.

Athani, S.I., Revanappa, R. and Dharmatti, P.R. (2009) Effect of plant density on growth and yield in banana. Karnataka J. Agric. Sci., 22(1),143-146.

Bassal, M.A. (2009) Effect of Tree Spacing on Growth and Fruit Production of Some New Citrus Cultivars in Egypt. Bull. Fac. Agric., Cairo Univ. 60, 2.

Basu, A. and Penugonda, K. (2008) Pomegranate juice: A heart healthy fruit juice. Nutr. Rev., 67, 49-56.

Bryla, D.R. and Strik, B.C. (2007) Effects of Cultivar and Plant Spacing on the Seasonal Water Requirements of High bush Blueberry. J. Amer. Soc. Hort. Sci., 132(2), 270277.

Callesen, O. and Wagenmakers, P.S. (1989) Effect of tree density, tree height and rectangularity on growth, flowering and fruit production. Acta Hort., 243,141-148.

Chadha, K.L. (2001) Orchard Planting and Layout. In Hand Book of Horticulture, ICA New Delhi. pp 36-40.

Donadio, L.C., Para, M. and Passam, H. (1995) Fruit quality of 'Pera' sweet orange (Citrus sinensis L. osbeck) grafted on the 'Cleopatra' mandarin (Citrus reshni, Hort. ex. Tanaka) at high density planting. Acta, Hort. 379, 1 .

Dubois, M., Gilles, K.A., Hamilton, J.K., Rebers, P.A. and Smith, F. (1956) Colorimetric method for determination of sugars and related substances. Anal. Chem., 28, 350-356.

Duncan, D. B. (1955) Multiple range and multiple F. Tests Biometrics, 11, 1-24.

Egypt. J. Hort. Vol. 40, No.1 (2013) 
El-Kassas, Sh.E, Mahmoud, H.M. and EL-Salhy, A.M. (1989) Effect of some growth regulators on fruit quality of Manfalouty pomegranate cultivar. Assiut $J$. Agric. Science. 20 (2), 51-70.

Ferreira de Sousa, C.A., Cavalcanti, M.I., Vasconcelos, L.F., Umbelino de Sousa, H.; Ribeiro, V.Q. and Lopes da Silva, J.L. (2012) Tommy Atkins mango trees subjected to high density planting in sub humid tropical climate in northeastern Brazil. Pesq. Agropec. Bras., Brasilia, 27 (1), 36-43.

Goswami, A.M., Saxena, S.K. and Kurein, S. (1993) High density planting in Citrus. Advances in Horticulture. 645-648.

Hampson, C.R., Quamme, H.A., Kappel, F. and Brownlee, R.T. (2004) Varying density with constant rectangularity: II. Effects on apple tree yield, fruit size and fruit color development in three training systems over ten years. HortScience, 39(3), 507-511.

Holland, D., Hatib, K. and Bar-Ya'akov, I. (2009) Pomegranate: Botany, horticulture, breeding. Hort. Rev., 35, 127-191.

Hsia, C.L., Luh, B.S. and Chichester, C.O. (1965) Anthocyanins in freestone peaches. J. Food Sci., 30, 5-12

Hunton, R.J. (1986) The influence of tree size control and plant density on citrus productivity. Acta Hort., 1750, 249-254.

Lansky, E.P. and R.A. Newman( 2007) Punica granatum (pomegranate) and its potential for prevention and treatment of inflammation and cancer. J. Ethnopharmacol, 109, 177-206.

Nasir, M.A., Mohar, T.A., Saeed, A. and Malik, A. (2006) Effect of Plant Spacing on the Growth and Quality of Kinnow Under Sargodha Climatic Conditions. Sarhad J. Agric., 22, I.

Robinson, T.T. (1997) Interaction of tree form and rootstock on light interception, yield and efficiency of "Empire", "Delicious" and "Jonagold" apple trees trained to different systems, Acta Hort., 451, 427-436.

Saxena, S.K. and Sharma, R.R. (2004) Studies on various criteria for predicting vigour of citrus plants. Int. Symp. Citriculture. p.64.

Sendecor, G.W. and Cochran, W.G. (1990) Statistical Methods. $7^{\text {th }}$ ed. Iowa State Univ. U.S.A. p.593.

Seeram, N.P., Schulman, R.N. and Heber, D. (2006) Pomegranates: Ancient roots to modern medicine. CRC Press, Boca Raton, FL.

Singh, G., Singh, A.K. and Mishra, D. (2005) High density planting in guava. ISHS Acta Horticulturae 735, I International Guava Symposium

Soliman, S.S. (1992) Effect of creation soil moisture levels on some physiological responses of Manfalouty Pomegranate trees. M. Sc. Thesis, Fac. Agric., Hort. Dept., Assuit Univ., Egypt. 
Testolin, R. (1990) Kiwifruit Yield Efficiency, Plant Density, and Bud Number per Surface Unit. J. AMER. Soc. Hort. Sci. 115(5), 704-707.

Tucker, D.P., Wheaton, T.A. and Muraro, R.P. (1994) Citrus tree spacing. Florida cooperative extension service. Univ., Florida. Fact Sheet HS-143. .

Wertheim, S.J. (1985) Productivity and fruit quality of apple in single-row and full-field planting systems. Scientia Hort., 26,191-208.

Wutscher, H.K. (1995) performance of Hamlin orange on 16 rootstocks in east - central Florida. Hort. Scince, 30(1), 41-43.

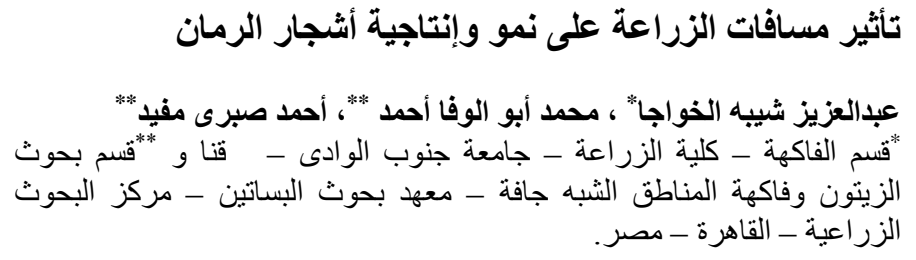

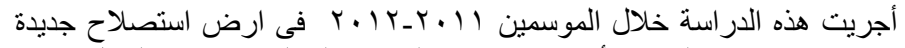



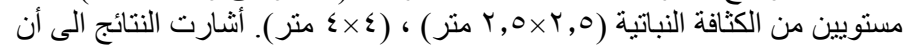



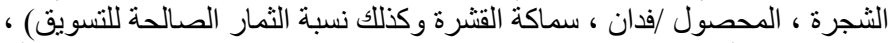



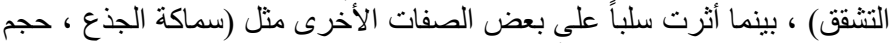

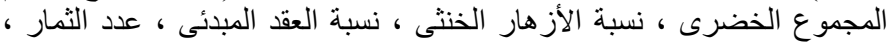



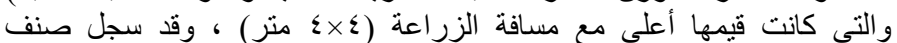

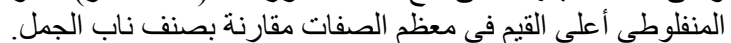

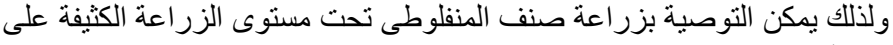

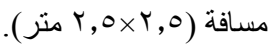

